Table 1. Changes with Age in the Polysaccharide Composition of THE MECOPOIYSACCHARIDE-PROTEIN COMPLEXES EXTRACTED FROM BOVINE NASAL CARTILAGE

$$
\begin{gathered}
\text { Embryonic } \\
\text { g/ Molar } \\
100 \mathrm{~g} \text { ratio* }
\end{gathered}
$$
g) Molar old

Glucosamine $\}$ (1) Hexose $\begin{array}{rr}2 \cdot 1 & 0 \cdot 09 \\ 0.8 & 0 \cdot 12\end{array}$ 2.80 .12 $21.9 \quad 0.84$ Uronic acid $\}(2)$ Ratio of keratan sulphate (1)/chondroitin sulphate (2) $0 \cdot 10$ $\begin{array}{ll}3.7 & 0.16\end{array}$ $\begin{array}{rr}4 \cdot 3 & 0 \cdot 19 \\ 20 \cdot 0 & 0 \cdot 84\end{array}$ $\begin{array}{ll}20 \cdot 0 & 0.84 \\ 19 \cdot 8 & 0 \cdot 77\end{array}$ $0 \cdot 19$
$0 \cdot 41$

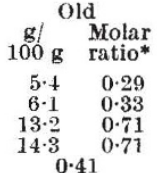

* The values are calculated using total hexosamine as 1.00.

Scott ${ }^{6}$. Analysis of this fraction for uronic acid, hexos. amine and hexose is shown in Table 1. The molar equivalence of (1) glucosamine and hexose and (2) of galactosamine and uronic acid indicated the presence of keratan sulphate and chondroitin sulphate in all three preparations. This was confirmed by the separation of the two mucopolysaccharides on cellulose columns as described by Gardell?.

The ratio of keratan sulphate to chondroitin sulphate as indicated by the proportion of glucosamine to galactosamine in Table 1 varied according to the age of the animal, while the total acid mucopolysaccharide content of the complexes remained relatively constant. The keratan sulphate content of the total mucopolysaccharide increased from 9.0 per eent in the embryonic preparation to 29 per cent in that of the old steer. These results suggest that the changes in the ratio of keratan sulphate to total mucopolysaccharide observed by Kaplan and Meyer $^{5}$ in human costal cartilage with increasing age are probably due to changes in the composition of the acid mucopolysaccharide complex present in this tissue.

This work was supported by a grant from the Australian Beef and Cattle Research Committee.

A. Tin-Wai GoH

Department of Biochemistry,

D. A. LOWTHER

Monash University,

Clayton, Victoria.

${ }^{1}$ Malawista, I., and Schubert, M., J. Biol. Chem., 230, 535 (1958).

${ }^{2}$ Gerber, B. R., Franklin, E. C., and Schubert, M., J. Biol. Chem., 235, 2870 $(1960)$.

$s$ Gregory, J, and Roden, I, Biochem, Biophys, Res, Commun, 5, 430 (1961).

- Goh, A. T. W., and Lowther, D. A (in preparation).

${ }^{5}$ Kaplan, D., and Meyer, K., Nature, 183, 1267 (1959).

- Scott, J. E., in Methnds of Biochemical Analysis, edit. by Glick, D., 8, 145 $(1960)$.

${ }^{7}$ Gardell, S., Acta Chem. Scand., 11, 668 (195i).

\section{Premature Birth in Rats induced by Ethionine Injection}

THE injection of pregnant rats with certain antimetabolites, such as ethionine, in sub-lethal doses, may result in resorption or stillbirth ${ }^{1-4}$. We wish to report the effect of smaller, repeated doses of ethionine on the course and outcome of pregnancy in rats. Daily subeutaneous injections, in the doses listed in Table 1, were given from the twelfth day of pregnancy until delivery. Control animals received saline injections. All injections were in a volume of $1 \mathrm{ml}$. The date of conception was established by the first appearance of sperm on vaginal smears.

Most of the litters from females receiving ethionine were born prematurely. The degree of prematurity was, in general, directly related to dose. These findings are outlined in Table $\mathrm{I}$. The birth weight deficits of the pups were no longer evident after ninety days.
We subsequently injected a group of non-pregnant female rats with single doses of ethionine in the lethal range. When the survivors were mated with norma males fertility was not impaired and young were delivered after a normal gestation period. The birth weights and growth rates of the pups were normal.

It is interesting to contrast the premature pups born to ethionine-treated mothers with those born at term to mothers whose dietary intake was restricted during pregnancy. Both types of pups result from a nutritional stress and both are underweight at birth. Their subsequent progress is, however, quite different. The premature pups attain full adult weight; the pups of restricted mothers remain underweight throughout their lives and also show other evidence of permanent damage ${ }^{5}$.

BACON F. ChOW

Conrado F. Agustiv

Department of Biochemistry,

School of Hygiene and Public Health,

The Johns Hopkins Tniver'sity, Baltimore, Maryland.

'Lee, C. M., Wiseman, J. T., Kaplan, S. A., and Warkany, J., Arch. Path., $59,232(1955)$.

2Marsh, M. E., Greenberg, I. D. and Rinehart, J. F., Fed. Proc., 14, 442 (1955).

${ }^{3}$ Schultz, R. I., Schultz, P. W., and Conn, A. A., Proc. Soc. Exp. Biol. Med., 105, $88(1960)$

${ }^{4}$ Proffit, W. R., and Edwards, L. E., J. Exp. Zool., 150, 135 (1962)

${ }^{5}$ Chow, B. F., and Iee, C. J., J. Nutrition, 82, 10 (1964).

\section{Relationship between Age and Haemoglobin- splitting Activity in Chicken Muscle}

Catheptic activity towards proteins has been found in extracts of kidney, spleen, liver, lung, muscle. brain and erythrocytes $^{1-5}$; therefore, the cathepsins may be considered to be part of the general enzymatic apparatus of animal cells. The action of the cathepsins is evident during the autolysis of animal tissues at acid $p H$. Recently, considerable interest has been shown in the catheptic activity of beef and chicken muscle because of their suggested rolo in meat tenderization, preservation and flavour 610

The function of the eathepsins in living tissue is not clearly known. Sylven and Malmgren ${ }^{21}$ have shown that the haemoglobin-splitting activity of young rapidly growing tumour cells is much greater than that of older tumour cell generations, and Ross and Ely ${ }^{12}$ found higher activity in young rats than in adult and older rats. These investigations suggest that cathepsins may play a part in protein turnover and synthesis.

The investigation reported here was undertaken to determine whether haemoglobin-splitting activity (protease activity at $p \mathbf{H} 3 \cdot 8$ ) in broiler chicken breast and thigh muscles ehanges during maturation. Such information is important in elucidating the physiological role of the haemoglobin-splitting cathepsins and can be of value as a means of determining maturity.

Six sets of broilers, $4,6,8,10,12$ and 14 weeks of age, were slaughtered by cutting the neck veins. The animals were bled and the breast and thigh muscles were removed. The tissue was immediately ground and then blended with distilled water. Haemoglobin-splitting activity was determined in tissue extracts by a modification ${ }^{13}$ of Ansor's ${ }^{14}$ method. The amount of tyrosine and tyrosinecontaining peptides liberated from denatured haemoglobin

\begin{tabular}{|c|c|c|c|c|c|c|c|c|}
\hline \multirow{2}{*}{$\begin{array}{l}\text { Dose of ethionine } \\
\text { (mg/rat/day) }\end{array}$} & \multirow{2}{*}{$\begin{array}{c}\text { No. of } \\
\text { pregnant rats }\end{array}$} & \multirow{2}{*}{$\begin{array}{l}\text { No. of rats show: } \\
\text { ing resorption }\end{array}$} & \multirow{2}{*}{$\begin{array}{l}\text { No, of rats with } \\
\text { live births }\end{array}$} & \multirow{2}{*}{$\begin{array}{l}\text { No. of rats with } \\
\text { stillbirths }\end{array}$} & \multicolumn{2}{|c|}{ Length of gestation* (days) } & \multicolumn{2}{|c|}{ Birth weight* $(g)$} \\
\hline & & & & & Mean & Range & Bican & Range \\
\hline $\begin{array}{c}0 \\
8 \cdot 5 \\
17 \\
35 \\
55 \\
70\end{array}$ & $\begin{array}{l}10 \\
1: 2 \\
30 \\
13 \\
10 \\
10\end{array}$ & $\begin{array}{l}0 \\
0 \\
5 \\
6 \\
6 \\
8\end{array}$ & $\begin{array}{r}10 \\
12 \\
25 \\
7 \\
4 \\
2\end{array}$ & $\begin{array}{l}0 \\
0 \\
3 \\
4 \\
4 \\
2 \\
2\end{array}$ & $\begin{array}{l}21 \cdot 1 \\
21 \cdot 5 \\
20 \cdot 1 \\
19 \cdot 2 \\
19 \cdot 4 \\
18 \cdot 5\end{array}$ & $\begin{array}{l}21-22 \\
21-22 \\
19-21 \\
17-20 \\
18-20 \\
18-19\end{array}$ & $\begin{array}{l}6 \cdot 3 \\
6 \cdot 1 \\
4 \cdot 2 \\
3 \cdot 5 \\
3 \cdot 2 \\
3 \cdot 0\end{array}$ & $\begin{array}{l}5 \cdot 9-7 \cdot 2 \\
5 \cdot 6-6 \cdot 8 \\
3 \cdot 4-5 \cdot 0 \\
2 \cdot 0-4 \cdot 5 \\
1 \cdot 9-3 \cdot 6 \\
1 \cdot 7-3.4\end{array}$ \\
\hline
\end{tabular}

Table 1 